\title{
脳波を用いた手足の運動想起判別における 準備電位の傾きを用いた特徴抽出法に関する検討"
}

\author{
中村 翔太郎 *・高橋 弘武*・吉川 大弘*・古橋 武*
}

\begin{abstract}
近年，脳情報を読み取り，機械の制御を行うBrain Computer Interface (BCI)の実現に向けて，脳波の判 別に関する研究が盛んに行われている。この脳波判別には，手足などの運動，もしくは運動想起が用いら れることが多い。一方，運動に関連する脳波パターンとして，運動前に電位が減少する準備電位 $(\mathrm{BP})$ があ る. BPでは, 動かす体の部位によって減少傾向が異なることが知られている，本論文では，BPの減少傾向 の違いに着目した特徵抽出法を提案する。 BCI Competition IIIで用いられた手足の運動想起時の脳波デー タに対して提案手法を適用し，その有効性を示す。
\end{abstract}

キーワード：Brain Computer Interface，運動想起，準備電位

\section{1. はじめに}

近年，脳の神経活動を外部の機器に取り込み，解析 することで，車椅子の制御や文字入力支援などに応用 するBrain Computer Interface (BCI)の研究が盛んに 行われている $[1][2] . B C I の$ 研究が進むことで将来的 に，筋萎縮性側索硬化症 (Amyotrophic Lateral Sclerosis：ALS）患者など, 脳機能のみが残存してい る人が，考えただけでものを動かしたり，会話をする ことが可能となることが期待されている，BCIの実現の ためには，思考の判別が必要不可欠である。このため の脳活動計測には非侵襲の測定が可能な脳波 (Electroencephalogram：EEG）がよく用いられ，また 思考の対象として手足の運動想起判別が数多くなされ ている。運動に関連する脳波の特徴として，運動前に 電位がゆっくり減少する準備電位（Bereitschschafts Potential：BP) があり，左右の手足など，体のどの部 位を動かしたかによって減少傾向が異なることが知ら れている $[3]$ 。左右の違いでは, 動かした部位と左右 反対側の脳において，BPの特徴が顕著に現れる。例 えば，左手指運動では，右脳の 1 次運動野付近におい て電位が減少する。また, 手足など, 部位の違いで は，足は頭頂部付近，手は側頭よりの 1 次運動野付近 において，特徴がより顕著に現れる。さらに，実際の

$\dagger$ A Study on Feature Extraction Method based on Regression Coefficient of Bereitschschafts Potential for Discrimination of Hand and Foot Motor Imagery using EEG

Shotaro NAKAMURA, Hiromu TAKAHASHI, Tomohiro YOSHIKAWA and Takeshi FURUHASHI

* 名古屋大学

Nagoya University
運動を行ったときのみでなく, 運動を想起した時の脳 波に扔いても，これらの特徴が現れることが知られて いる．BPを利用した脳波判別に関する過去の研究で は，例として，Liらが左右の手足など，動かした体の 部位によりBPの減少傾向が異なることに着目し，多 次元時系列データであるEEGデータから，2 思考の 分散比を最大にする軸を抽出するCommon Spatial Subspace Decomposition(CSSD) [4]を用いた判別を 行っている[5][6]。しかし，CSSDでは分散比を特徵 量としているため, 必ずしも減少傾向の違いを効果的 に捉えることができるとは限らない。これに対し著者 らは, BPの減少傾向の違いに着目し，回帰分析を用 いた特徴抽出法を提案し, 実運動時のEEGデータを 用いて有効性の検証を行ってきた[7].

本論文では, 左手と右足の運動想起データである BCICompetition IIIのdata set IVc[8]に対して提案手 法を適用し，炎の有効性に対する検証を行う。また， 適切なパラメータ設計を行うことにより, 従来手法で あるCSSDよりも高い判別率が得られることを示す。

以下， 2 章で提案手法を説明し， 3 章において, 運 動想起データを用いた実験により提案手法の有効性を 検証する。最後に 4 章でまとめる.

\section{2. 提案手法}

2 思考の運動想起時に打ける, 電極数 $N$ のEEGデー 夕を対象とし，それぞれの思考の特徴を抽出する。提 案手法では, BPによる減少傾向について, 部位によ る違いに着目し，次の 2 つ条件を満たす空間フィル 夕を作成する。（i） 2 思考厹れ公れを直線近似した時 の傾きの差を最大化し，かつ(ii) 2 思考皇れぞれにお 
ける，各試行の傾きの分散を最小化する。四 1 に，左 手, 右足それぞれの運動想起時のEEGデータの例を 示す.グラフ中の各線が各部位の電位を表している. 罒より, 部位によって, 準備電位の減少傾向が異なっ ていることがわかる.

まず $x_{t}^{h}, x_{t}^{f}$ をそれぞれ時刻 $t(=1,2, \cdots, T)$ におけ る左手, 右足の運動想起時の脳波データ, $\boldsymbol{w}\left(\in \mathbf{R}^{N}\right)$ を 空間フィルタとする. ただし,$\frac{1}{T} \sum_{t=1}^{T} x_{t}^{h}=\frac{1}{T} \sum_{t=1}^{T} x_{t}^{f}=$ 0 とする。次に, フィルタ適用後のデータ $\boldsymbol{y}_{t}^{h}, \boldsymbol{y}_{t}^{f}$ に対 し，以下の回帰モデルを仮定する。

$\boldsymbol{y}_{t}^{h} \equiv \boldsymbol{w}^{\prime} \boldsymbol{x}_{t}^{h}=a_{h}(t-\bar{t})$

$\boldsymbol{y}_{t}^{f} \equiv \boldsymbol{w}^{\prime} \boldsymbol{x}_{t}^{f}=a_{f}(t-\bar{t})$

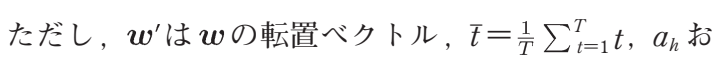
よび $a_{f}$ は回帰係数である。 $a_{h}, a_{f}$ についてはそれぞ れ式(3)，式(4)で表すことができる.

$a_{h}=\frac{\frac{1}{T-1} \sum_{t=1}^{T} \boldsymbol{w}^{\prime} \boldsymbol{x}_{t}^{h}(t-\bar{t})}{\frac{1}{T-1} \sum_{t=1}^{T}(t-\bar{t})^{2}}=\frac{\boldsymbol{w}^{\prime} S_{t} \boldsymbol{x}_{t}^{h}}{S_{t}^{2}}$

$a_{f}=\frac{\frac{1}{T-1} \sum_{t=1}^{T} \boldsymbol{w}^{\prime} \boldsymbol{x}_{t}^{f}(t-\bar{t})}{\frac{1}{T-1} \sum_{t=1}^{T}(t-\bar{t})^{2}}=\frac{\boldsymbol{w}^{\prime} S_{t} \boldsymbol{x}_{t}^{f}}{S_{t}^{2}}$

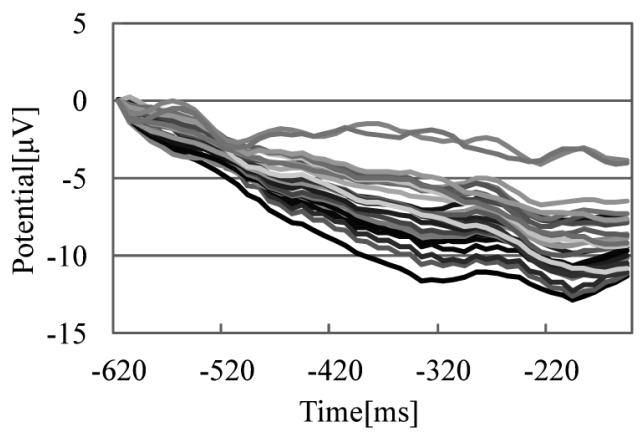

(a) left hand

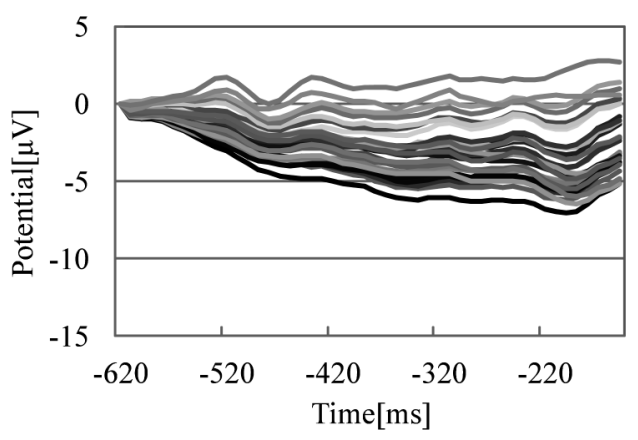

(b) right foot

図 12 思考のBPの違い
ただし $, S_{t} \boldsymbol{x}_{t}^{h}=\frac{1}{T-1} \sum_{t=1}^{T}(t-\bar{t}) \boldsymbol{x}_{t}^{h}, S_{t}^{2}=\frac{1}{T-1} \sum_{t=1}^{T}(t$ $-\bar{t})^{2}$ とする。 $a_{h}, a_{f}$ を用い, 傾きの差の 2 乗である 式(5)が得られる.

$\left(a_{h}-a_{f}\right)^{2}=\frac{\boldsymbol{w}^{\prime}\left(S_{t} \boldsymbol{x}_{t}^{h}-S_{t} \boldsymbol{x}_{t}^{f}\right)\left(S_{t} \boldsymbol{x}_{t}^{h}-S_{t} \boldsymbol{x}_{t}^{f}\right)^{\prime} \boldsymbol{w}}{S_{t}^{2} S_{t}^{2}}$

ここで，式(3)，式(4)において，フィルタ適用前の回 帰係数 $\boldsymbol{a}_{h}$ 打よび $\boldsymbol{a}_{f}$ は式 (6), 式 (7)のように回帰係数 の列べクトル $\left(\in \mathbf{R}^{N}\right)$ で表すことができる.

$\boldsymbol{a}_{h}=\frac{S_{t} \boldsymbol{x}_{t}^{h}}{S_{t}^{2}}$

$\boldsymbol{a}_{f}=\frac{S_{t} \boldsymbol{x}_{t}^{f}}{S_{t}^{2}}$

さらに $\boldsymbol{a}_{h}(m), \boldsymbol{a}_{f}(m)$ をそれぞれ $m(=1,2, \cdots, M)$ 試 行目のデータに対して回帰分析を適用したときの回帰 係数べクトルとすると, 試行間の分散共分散行列は式 (8)，式(9)で表される.

$V^{h}=\frac{1}{M-1} \sum_{m}^{M}\left(\boldsymbol{a}_{h}(m)-\overline{\boldsymbol{a}_{h}}\right)^{\prime}\left(\boldsymbol{a}_{h}(m)-\overline{\boldsymbol{a}_{h}}\right)$

$V^{f}=\frac{1}{M-1} \sum_{m}^{M}\left(\boldsymbol{a}_{f}(m)-\overline{\boldsymbol{a}_{f}}\right)^{\prime}\left(\boldsymbol{a}_{f}(m)-\overline{\boldsymbol{a}_{f}}\right)$

ただし,$\overline{\boldsymbol{a}_{h}}=\frac{1}{M} \sum_{m=1}^{M} \boldsymbol{a}_{h}(m)$ である.フィルタ適用後 の各運動想起時の分散の合計は次式となる。

$\boldsymbol{w}^{\prime}\left(V^{h}+V^{f}\right) \boldsymbol{w}$

$\boldsymbol{w}$ に関係ない $S_{t}^{2}$ を除いた式(5)の分子と式(10)の比を 最大にする式(11)により, 前述の 2 つの条件を満たす を求めることができる.

$\max _{w} \frac{\boldsymbol{w}^{\prime}\left(S_{t} \boldsymbol{x}_{t}^{h}-S_{t} \boldsymbol{x}_{t}^{f}\right)\left(S_{t} \boldsymbol{x}_{t}^{h}-S_{t} \boldsymbol{x}_{t}^{f}\right)^{\prime} \boldsymbol{w}}{\boldsymbol{w}^{\prime}\left(V^{h}+V^{f}\right) \boldsymbol{w}}$

未知データ $X$ に対しては, フィルタ $\boldsymbol{w}$ に適用後, 線 形回帰分析を行い, 次式から得られる傾きを特徴量 $f$ として用い，判別を行う.

$f=\frac{\boldsymbol{w}^{\prime} S_{t} \boldsymbol{x}_{t}}{S_{t}^{2}}$

\section{3. 実験}

\section{1 実験データ}

EEGデータとして, BCI Competition IIIのdata set $\operatorname{IVc}[8]$ [9]を用いた。このデータは1名の被験者から 計測されたものである。計測は学習データ用とテスト 
データ用に計 2 回行われ，それらの間に 3 時間以上の 休鄎を挟んである。学習データの測定に打いては，各 試行について，被験者は“左手”か“右足”のどちらかの 視覚呈示に従い，運動想起を $3.5 \mathrm{~s}$ 間行った。その後呈 示が消え，1.75〜2.25s間のランダムな長さの休鄎を 挟み, 次の視覚呈示が始まる。これを 3 セッション (各セッション 70 試行)行うことで, 各思考 105 試行ず つの学習データが得られた。またテストデータについ ては，運動想起の時間は1s間であり，さらに“リラッ クス”のタスクを加えた 3 つのタスクついて，各思 考140試行ずつ得られている。なお，“リラックス”の タスクについては, 被験者には運動想起をしてはなら ないと指示されている。これらのEEGデータは118個 の電極から計測され，サンプリング周波数は $1000 \mathrm{~Hz}$ であった。

\section{2 判別手順}

提案手法での判別手順を図 2 に示す。運動と関係の ない電極はフィルタを作成する際のノイズとなる可能 性があるため, 運動野付近とその周辺の26電極(図 3 )

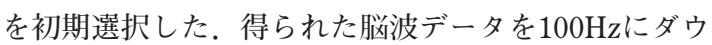
ンサンプリングした後, 準備電位を抽出するため, 0$3 \mathrm{~Hz}$ の通過域をもつlow-pass filter (LPF) を適用した。

図 4 に, 図 3 の26電極について, 視覚呈示後の全試行 電位平均值の時間推移を示す。なお図 4 では, LPFの 適用後， $0 \mathrm{~s}$ の電位が $0 \mu \mathrm{V}$ となるように規格化してい る. 図 4 より, 約 $0.5 \mathrm{~s}$ 後以降に打いて，2 思考の電位 の時間推移が異なっていることがわかる，そこでこの 特徴を捉えるために，提案手法を適用した。ただし提 案手法では, 適切な時間空の選択が必要となる。そこ で本実験では，学習データに対しleave-one-out法を 適用したときの判別率を基準とし, 適切な時間空を選 択した。さらに，2思考の電位の時間推移に差がない 電極については，フィルタを作成する際のノイズとな る可能性があるため, leave-one-out法による判別率 を基準として電極選択を行った。得られた特徴量 $f$ を 用い, 線形判別分析 (Linear discriminant analysis : LDA）により思考判別を行った.

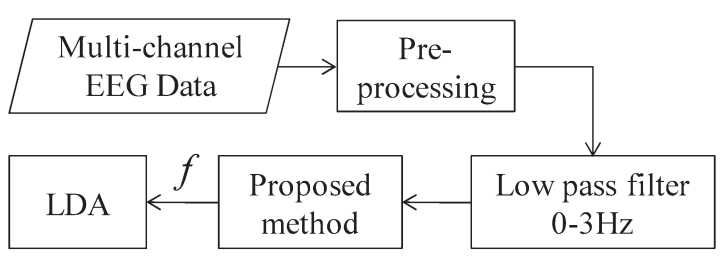

図 2 判別手順

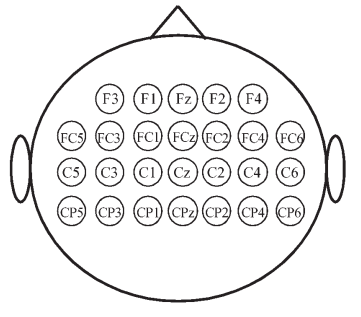

図 3 初期電極配置

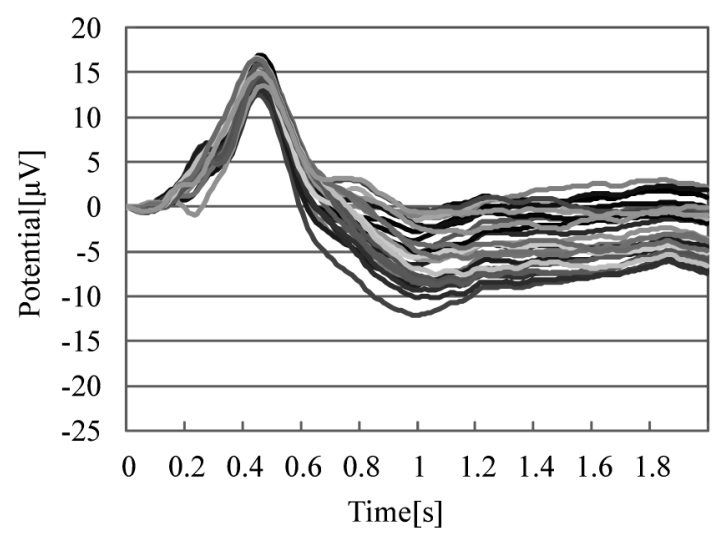

(a) left hand

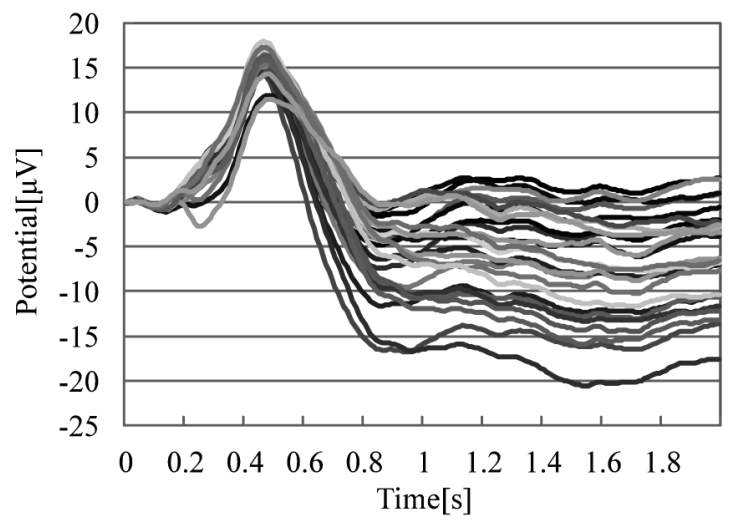

(b) right foot

図 4 視覚呈示後の電位の全試行平均時間推移 (26電極)

\section{3 結果と考察}

\subsection{1 時間空の選択}

0sを視覚呈示が始まった時刻とする。初めに，空の 長さを $300 \mathrm{~ms}$ に固定し，空の開始点を $-1 \sim 1 \mathrm{~s}$ の間で $10 \mathrm{~ms}$ ずつ変化させたときの判別率を図 5 に示す。罒 から, 判別率のピークが視覚呈示後であることが確認 でき，空の長さを $300 \mathrm{~ms}$ に固定した場合，空の開始点 を視覚呈示後 0.39 sにしたときに最高判別率 $84.3 \%$ を 


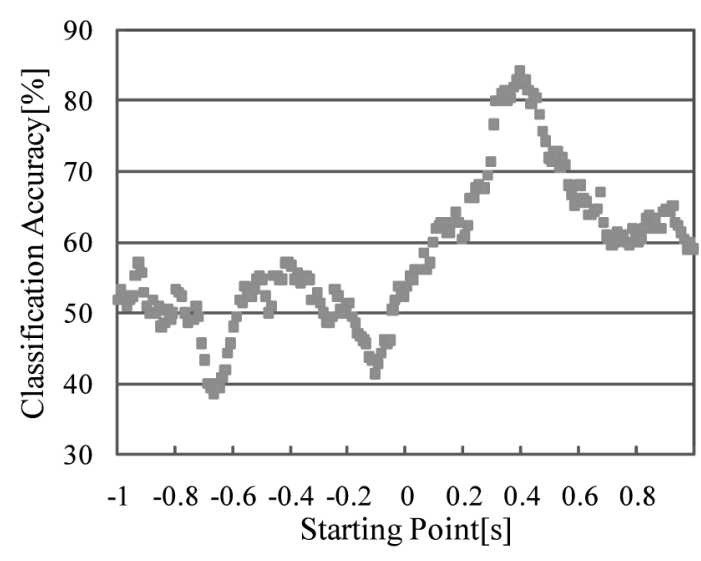

図 5 判別率の推移(時間空：300ms)

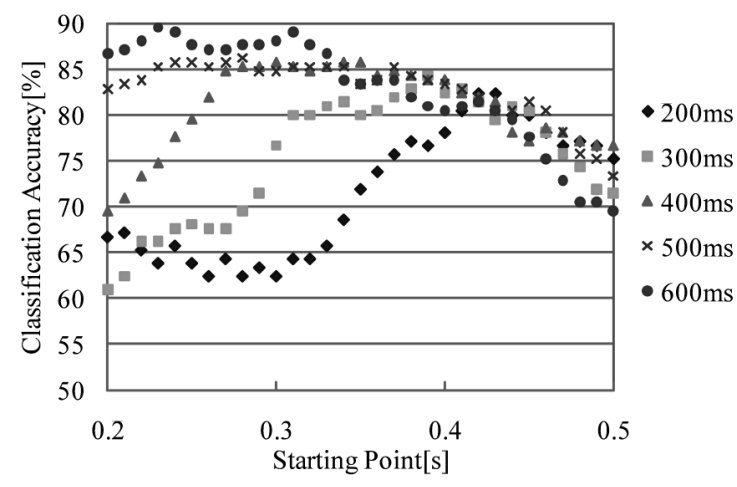

図 6 判別率の推移(時間空：200 600ms)

得た。

同様に空の長さを $200 〜 600 \mathrm{~ms}$ の範囲で100msずつ 変化させ，それぞれ空の開始点を運動直後である 0.1 ～ $0.6 \mathrm{~s}$ の間で $10 \mathrm{~ms}$ ずつ変化させた時の判別率の推移 を図 6 に示す。この結果から, 初期選択電極での適切 な時間空は, 開始点が $0.23 \mathrm{~s}$, 空の長さが $600 \mathrm{~ms}$ であ り，このときの判別率は $89.5 \%$ となった。

図 4 に打いて, どちらの思考についても視覚呈示後 約 $0.4 \mathrm{~s}$ で電位のピークをもち, その後電位が減少して おり, さらに左手よりも右足の方が電位の減少の程度 が大きいことがわかる。図 6 より，どの長さの時間空 に打いても，その傾向が時間空内に含まれている時に 判別率が高くなっており, 提案手法が, 減少傾向の違 いを捉えることができたと考えられる。次に，学習 データの各思考 105 試行に対し，フィルタ適用前後で の傾きの平均をエラーバー付きで図 7 に示す。なお， フィルタ適用前については全電極の平均值を用いて傾 きを計算して打り，フィルタ適用後については空の長 さが600msのときのフィルタを用いている．眓 7 (a), (b)より，フィルタを適用することで， 2 思考の傾き

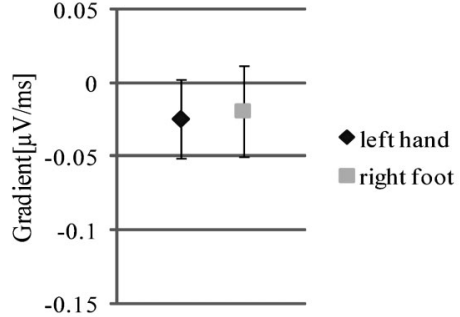

(a) Before the projection

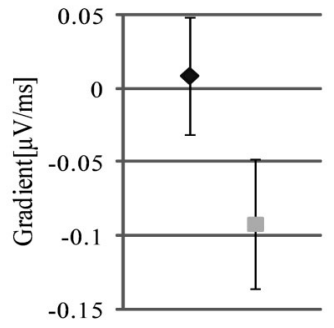

(b) After the projection (starting point $: 0.23 \mathrm{~s}$ )

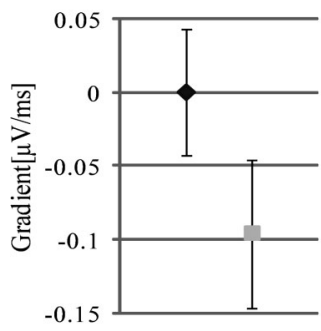

(c) After the projection (starting point $: 0.45 \mathrm{~s}$ )
図 7 フィルタ適用による 2 思考の傾きの差

の差が大きくなっていることがわかる。また図 7 (c) は, 図 4 に打ける電位のピークである $0.45 \mathrm{~s}$ 空の開 始点にした場合の 2 思考の分布である. 図 7 (b) と (c) を比べると, 傾きの差はほとんど変わらないが, 試行 間の分散が $(\mathrm{c})$ よりも (b)の方が小さいことがわかる. このことが, 図 6 において, $0.23 \mathrm{~s} て ゙$ 判別率が最大に なった要因であると考えられる。

\subsection{2 電極選択}

提案手法により得られるフィルタにおいて，1つず つ電極を抜き, 最も判別率の高い電極配置を採用す る. 初期電極配置 (図 3 ) から 1 電極ずつ抜き (26通 り), 各空でのLeave-one-outによる判別率を再計算 する. $200 〜 600 \mathrm{~ms} の 5 つ の$ 空における最高判別率の 平均值を比べ, 最も高かった電極配置を採用する。削 除前の最高判別率と比較し, 採用された電極配置での 判別率のほうが高ければ，その電極配置からさらに 1 電極ずつ抜き, 最高判別率を比較する。電極選択の手 順を以下に示す。

(1) 電極ずつ抜き，各空でのLeave-one-outによる判 別率を再計算する。

(2) 各空での最高判別率の平均を算出し, 最も高かっ た電極配置を採用する。

(3) 削除前の最高判別率の平均と比較し, 削除後の判 別率の方が高ければ(1)へ戻る.

(4)最後に削除された電極を採用する. 


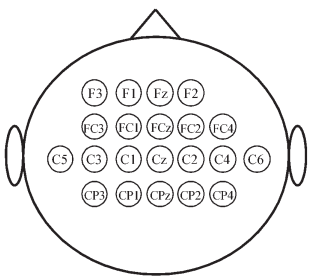

(a) Proposed method

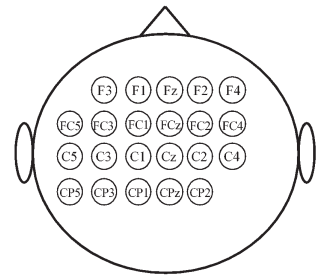

(b) CSSD
図 8 選択された電極

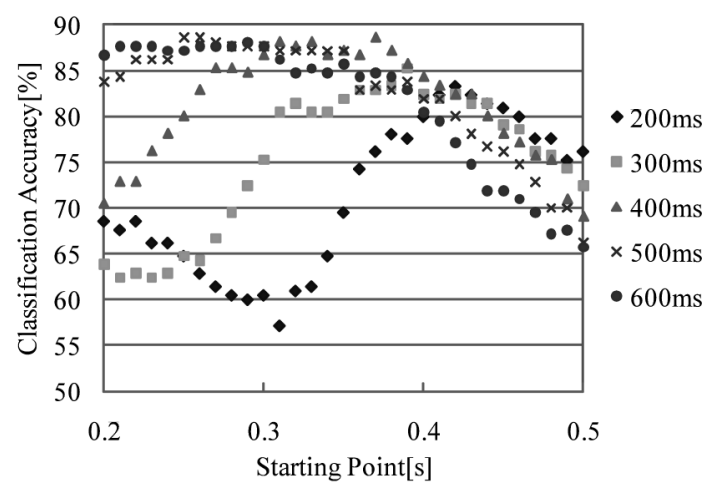

図 9 判別率の推移(時間空：200 600ms)

これにより，本学習データでは 5 つの電極が削除さ れた。削除後の電極を図 8 (a)に示す。またこのとき の各空の判別率の推移を図 9 に示す。以上の結果か ら, 電極配置は図 $8(\mathrm{a})$, 時間空は開始点が $0.37 \mathrm{~s}$, 空 の長さが $400 \mathrm{~ms}$ のとが最も高い判別率を示し，この ときの判別率は $88.6 \%$ となった。この時間空により得 られた特徴量 $f$ を用いて学習モデルを作成し, テスト データ(リラックスを除く)に対する判別率を算出した ところ, $86.0 \%$ となった。

また図 8 (a)より, フィルタの係数に基づく電極選 択によって，主に頭頂部から離れた端の方の電極が削 除されたことがわかる。これは，BPなどの運動に関 連する電位は運動野に対応する $\mathrm{C} 3, \mathrm{C} z, \mathrm{C} 4$ 付近にお いて優位に現れるという知見と一致する $[3]$.

\section{4 従来手法との比較}

従来手法との比較を行う。従来法であるCSSDにお いても，3.3.1，3.3.2で示した方法と同様に，学習 データを用いてパラメータ設計を行った。選択された 電極を図 8 (b)に示す.CSSDにおいても, 電極選択 によって主に頭頂部から離れた端の方の電極が削除さ れていることがわかる。また, 時間空の開始点は $0.35 \mathrm{~s}$, 空の長さは $600 \mathrm{~ms}$ が得られた(図10)。このと きの学習データでの判別率は $80.0 \%$ あり, この設定

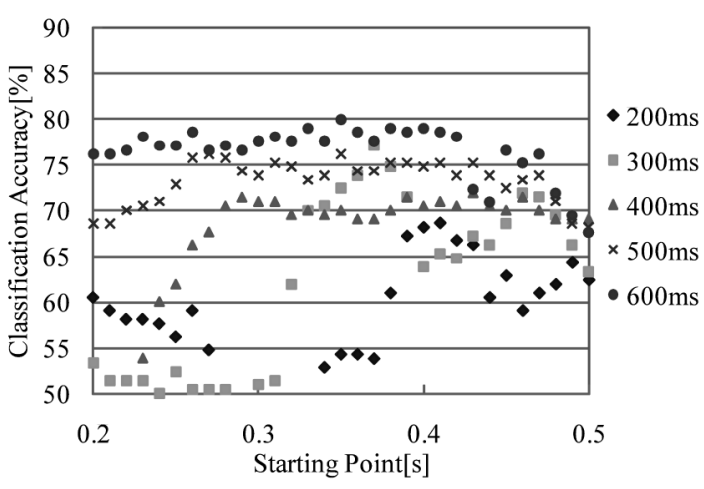

図10 CSSDを用いた場合の判別率の推移

（時間空：200～600ms）

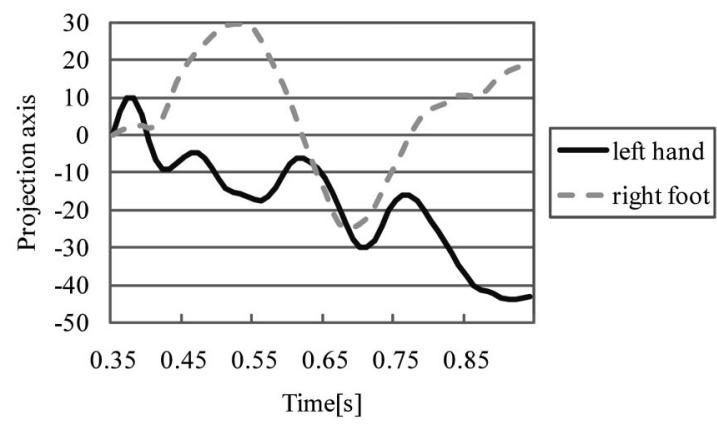

図11 フィルタ適用後の 2 思考の時間推移の例

を用いてテストデータに適用したところ, 判別率は 79.3\%となった。CSSDにより得られたフィルタ適用 後の2思考の時間推移の例を図11に示す。CSSDでは 分散比を特徴量としているため, 図の例では, 左手に おいて電位の減少がみられるにもかかわらず, 分散に よる差が小さくなってしまっている. 提案手法では, $\mathrm{BP}$ による減少傾向の違いを適切に捉えることで, CSSD と比較して高い判別率が得られたと考えられ る.

\subsection{Competition winner手法との比較}

本実験で用いたBCI Competition IIIのdata set IVc におけるコンペティション成績 1 位の手法 [10] (手法 Aと呼ぶ)との比較を行う。手法Aでは, 運動に関連す る脳波の特徴である事象関連脱同期 (Event-Related Desynchronization：ERD)に対してCSSDを適用し， 特徵抽出を行っている. $\mathrm{ERD} も \mathrm{BP}$ 同様, $\alpha$ 波帯や $\beta$ 波帯での帯域強度において減少傾向の違いがあること が知られている. 本コンペティションではリラックス タスクの判別も行っており, 手法Aは初めにリラック スタスクと運動想起タスクとを判別してから左手と右 
足の判別を行うアルゴリズムとなっているため, コン ペティション通りの性能比較は行えないが，ERDを 利用し, band-pass filter(BPF)の適用後, CSSDを用 いて特徴抽出を行う方法を手法Aとして提案手法と比 較する. BPF適用後の学習データに対して，3.3.1と同 様の方法により時間空の設定を行った結果，開始点が 視覚呈示から $0.6 \mathrm{~s}$, 空の長さが $400 \mathrm{~ms}$ とき最高判別 率 $89.5 \%$ を示した。この設定を用いてテストデータに 適用したところ，判別率は $87.9 \%$ となった，提案手法 によるテストデータの判別率は3.3.2で示した通り 86.0 \%であるため, 手法Aの方が高い判別率を示したこと がわかる.

しかしながら提案手法で用いている特徴量は手法A とは異なるものであるため, これらから得られる特徴 量を組み合わせて判別することが可能である。そこ で，提案手法による特徵量 $f$ (式 (12)) と手法Aによる 特徵量 (分散比) との 2 次元ベクトルに対するLDAによ り判別を行った。矢の結果, 学習データでの判別率 $98.0 \%$ ，テストデータでの判別率 $93.3 \%$ を得た。

\section{4. まとめ}

本論文では，BCI Competition IIIのdata set IVcの データを用いて，左手／右足の運動想起判別を行っ た。異なる運動での電位の時系列パターンの違いに基 づいて，回帰分析を用いた特徴抽出法を提案し，運動 想起データに適用した。適切な時間空の選択および適 切な電極の選択を行うことで，テストデータにおいて 判別率 $86.0 \%$ を達成した。 またこの判別率が, 従来手 法であるCSSDに打いて同様のパラメータ設計を行っ た場合と比較して，高い判別率であることを示した。 コンペティションの成績 1 位の手法と提案手法とを組 み合わせることで, 各手法よりもさらに高い判別率が 得られることを示した。 今後は，本論文では対象とし なかったリラックスタスクの判別についても行ってい く予定である.

\section{謝辞}

本研究の一部は, 文部科学省科学研究費 (基盤研究 (C)，No.22500200)の補助を得て遂行された.

\section{参 考 文 献}

[1] N. Birbaumer, N. Ghanayim, T. Hinterberger, et al: A Spelling Device for the Paralyzed, Nature, Vol.398, pp.297-298, 1999.

[2] 高橋弘武, 吉川大弘, 古橋武: BCIの通信モデル化と 思考判別への二元消失通信路の導入. 電子情報通信学 会論文誌 D., Vol.J92-D, No.1, pp.153-161, 2009.

[ 3 ] J. A. Pineda, B. Z. Allison, and A. Vankov : The Effects of Self-Movement, Observation, and Imagination on $\mu$ Rhythms and Readiness Potentials (RP's) : Toward a Brain-Computer Interface (BCI), IEEE Trans. Rehab. Eng., Vol.8, pp.219-222, 2000.

[ 4 ] Y. Wang, P. Berg, and M. Scherg : Common spatial subspace decomposition applied to analysis of brain responses under multiple task conditions: A simulation study, Clin. Neurophysiol., Vol.110, pp.604-614, 1999.

[ 5 ] Y. Li, X. Gao, and H. Liu : Classification of SingleTrial Electroencephalogram During Finger Movement, IEEE Trans. Biomed. Eng., Vol.51, pp.10191025, 2004.

[ 6 ] Y. Wang, Z. Zhang, Y. Li, et al : BCI Competition 2003Data Set IV : An Algorithm Based on CSSD and FDA for Classifying Single-Trial EEG, IEEE Trans. Biomed. Eng., Vol.51, pp.1081-1086, 2004.

[ 7 ] 中村, 吉川, 古橋: 手指運動時の脳波判別に対する空 間フィルタ適用に関する一検討, 電子情報通信学会情 報・システムソサイエティ総合大会特別号, p.142, 2009.

[ 8 ] G. Dornhege, B. Blankertz, G. Curio, et al : Boosting bit rates in non-invasive EEG single-trial classifications by feature combination and multi-class paradigms., IEEE Trans. Biomed. Eng., Vol.51, pp.9931002, 2004.

[ 9 ] B. Blankertz, K. - R. Müller, D. J. Krusienski, et al : The BCI Competition III : Validating Alternative Approaches to Actual BCI Problems, IEEE Trans. Neural Syst. Rehabil. Eng., Vol.14, No.2, 2006

[10] D. Zhang, Y.Wang, X. Gao, et al : An Algorithm for Idle-State Detection in Motor-Imagery- Based BrainComputer Interface, Computational Intelligence and Neuroscience, Vol.2007, Article ID 39714, 9 pages, 2007

(2009年12月 4 日 受付)

(2010年 5 月22日 採録)

[問い合わせ先]

干464-8603 愛知県名古屋市千種区不老町

名古屋大学大学院工学研究科計算理工学専攻

高橋 弘武

TEL : 052-789-2793

E-mail : takahashi@cmplx.cse.nagoya-u.ac.jp 


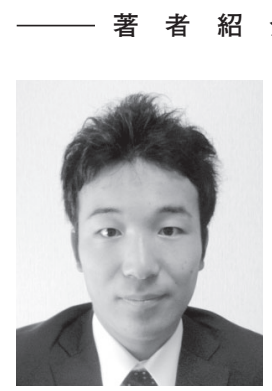

介

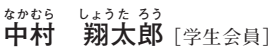

2008 年名古屋大学工学部電気電子 情報工学科卒業. 2010 年名古屋大学 大学院工学研究科博士前期課程計算理 工学専攻修了.同年西日本電信電話株 式会社入社. 現在に至る. 在学中は主 として脳波を用いた思考認識に関する 研究に従事.

\section{拮川妿 大弦 [正会員]}

1997 年名古屋大学大学院博士課程 修了. 同年カリフォルニア大学バーク レー校ソフトコンピューティング研究 所客員研究員. 1998 年三重大学工学 部助手. 2005 年名古屋大学大学院工 学研究科 COE 特任准教授. 2006 年 10 月同研究科准教授. 現在に至る. 主と してソフトコンピューティングとその 応用に関する研究に従事。博士（工 学)

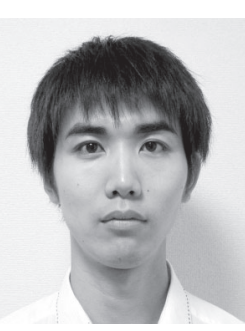

\section{唯は橋 弘武 [学生会員]}

2009 年名古屋大学大学院工学研究 科博士前期課程修了. 現在, 名古屋大 学大学院工学研究科博士後期課程在 学, 日本学術振興会特別研究員 DC2. 神経科学・工学に関心があり, ブレイ ンコンピュータインターフェイスに関 する研究に従事. IEEE, 日本知能情報 ファジィ学会, 電子情報通信学会会 員.

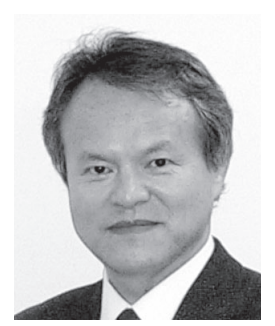

ふるはし たけし
古橋 武 [正会員]

昭和 60 年名古屋大学大学院工学研 究科博士後期課程電気系専攻修了. 工 学博士. 平成 16 年名古屋大学大学院 工学研究科計算理工学専攻教授. 現在 に至る。ソフトコンピューティング, 感性工学に関する研究に従事。平成 8 年日本ファジィ学会論文賞受賞. IEEE, 日本知能情報ファジィ学会, 電 気学会等の会員

\section{A Study on Feature Extraction Method based on Regression Coefficient of Bereitschschafts Potential for Discrimination of Hand and Foot Motor Imagery using EEG by \\ Shotaro NAKAMURA, Hiromu TAKAHASHI, Tomohiro YOSHIKAWA and Takeshi FURUHASHI}

\section{Abstract :}

Recently, a lot of researches on Brain-Computer Interfaces (BCIs) have been reported. It is expected that BCIs will help patients like those with Amyotrophic Lateral Sclerosis (ALS) to control a wheel chair or to communicate with other people just by using thoughts. BCIs analyze biological signals such as Electroencephalogram (EEG) to recognize thoughts, and especially those associated with motor imagery have been well investigated. The Bereitschschafts Potential (BP) is one of the features of EEGs related to body movements, which occurs before voluntary limb movements. The BPs associated with different movements have different temporal patterns. This paper proposes a method to capture the difference of the BP patterns. In this paper, the proposed method is applied to EEGs of motor imagery used in BCI Competition III and the effectivenesss of the proposed method is shown.

Keywords : Brain-Computer Interface, Motor Imagery, Bereitschschafts Potential

\section{Contact Address : Hiromu TAKAHASHI}

Department of Computational Science and Engineering, Graduate School of Engineering, Nagoya University

Furo-cho, Chikusa-ku, Nagoya 4648603, JAPAN

TEL : + 81-52-789-2793

E-mail : takahashi@cmplx.cse.nagoya-u.ac.jp 